\title{
PENGARUH PROBLEM SOLVING LABORATORY MENGGUNAKAN PENDEKATAN KONFLIK KOGNITIF TERHADAP PERUBAHAN KONSEP FISIKA SISWA SMA NEGERI 5 PALU
}

\author{
Sitti Hadija, Nurjannah dan Jusman Mansyur \\ Khadijaamatullah221@yahoo.com \\ Program Studi Pendidikan Fisika FKIP Universitas Tadulako \\ Jl. Soekarno Hatta Km. 9 Kampus Bumi Tadulako Tondo Palu - Sulawesi Tengah
}

\begin{abstract}
Penelitian ini bertujuan mendeskripsikan pengaruh problem solving laboratory menggunakan pendekatan konflik kognitif terhadap perubahan konsep fisika siswa SMA Negeri 5 Palu. Metode yang digunakan adalah the non equivalen, pretest-postest design. Populasi dalam penelitian ini adalah seluruh siswa Kelas XI IPA SMA Negeri 5 Palu tahun pelajaran 2014/2015 yang terdiri dari 4 kelas. Pengambilan sampel dilakukan tanpa penugasan random dan menggunakan kelompok yang sudah ada (inact group). Sampel dalam penelitian ini yaitu siswa Kelas XI IPA 3 sebagai kelas eksperimen dan Kelas XI IPA 2 sebagai kelas kontrol. Instrumen yang digunakan adalah tes perubahan konsep bentuk essai. Pengujian hipotesis dilakukan dengan statistik parametrik uji-t pihak kanan pada taraf signifikan $\alpha=0,05$. Hasil penelitian menunjukkan bahwa terdapat pengaruh yang signifikan terhadap perubahan konsep fisika siswa berupa peningkatan hasil posttest dibandingkan dengan hasil pretest.
\end{abstract}

Kata Kunci: Problem solving laboratory, pendekatan konflik kognitif dan perubahan konsep.

\section{PENDAHULUAN}

Selama ini berbagai macam model dan metode pembelajaran terus berkembang untuk mencapai tujuan pembelajaran yang diinginkan. Namun fakta yang terjadi adalah masih banyak guru yang terkesan mengesampingkan pemahaman konsep fisika siswa dan terfokus pada hafalan rumus-rumus. Salah satu faktor yang mempengaruhi rendahnya kualitas pendidikan terutama pendidikan sains di Indonesia adalah banyaknya konsep yang dikembangkan dalam kurikulum tidak berhubungan secara langsung dengan lingkungan siswa sehingga ketika diperkenalkan konsep dan aplikasi konsep tersebut siswa merasa asing. Mata pelajaran fisika erat kaitannya antara konsep dan lingkungan sekitar, peserta didik dengan mudah mengaplikasikannya dalam kehidupan seharihari. Pembelajaran fisika yang hanya menghafal persamaan tanpa memperhatikan konsepnya juga menyebabkan permasalahan kesulitan dalam pembelajaran ${ }^{[1]}$.

Dalam pembelajaran fisika yang ideal di sekolah SMA/MA, siswa diharapkan tidak hanya menguasai konsep-konsep fisika secara teori tetapi juga mampu menggunakan metode ilmiah untuk membuktikan konsep-konsep fisika melalui eksperimen. Hampir semua dasar-dasar fisika yang diajarkan kepada siswa didasarkan pada percobaan/eksperimen. Mata pelajaran berbasis laboratorium seperti fisika memberikan kesempatan alami kepada siswa untuk belajar melakukan suatu percobaan dan menganalisa data yang diperoleh sesuai tujuan percobaan yang dilakukan.

Mustafit $d k k^{\left[{ }^{2]}\right.}$ menyatakan bahwa problem solving laboratory yang digunakan dipandang efektif sebagai model pembelajaran yang dapat meningkatkan pemahaman konsep siswa. Berdasarkan hasil analisis statistik, terdapat persentase penguasaan keterampilan proses pada aspek psikomotorik, aspek afektif dan aspek kognitif. Persentase aspek psikomotorik pada indikator kreatifitas dalam kegiatan laboratorium yang paling besar adalah mahasiswa dapat merangkai alat-alat eksperimen sendiri.

Menurut ahli psikologi kognitif $^{[3]}$, timbulnya kesalahan konsep disebabkan adanya asimilasi dan akomodasi pada otak manusia dalam menanggapi dan memahami informasi yang baru diterimanya. Sebelum belajar fisika, dalam struktur kognitif siswa telah terbentuk berbagai pra konsepsi mengenai peristiwa dan pengertian tentang konsep-konsep fisika. Hal yang perlu disadari adalah bahwa belum tentu pra konsepsi tersebut benar dan sesuai dengan 
pengalaman nyata. Dalam kondisi semacam ini, jika konsep-konsep baru langsung saja dimasukan dalam struktur kognitif siswa akan terjadi pencampuran konsep lama (yang belum tentu benar) dan konsep baru yang mungkin juga belum tentu dipahami secara benar pula. Akibat pencampuran ini menjadikan pengertian yang salah dan akan menyebabkan kesulitan belajar siswa dalam belajar fisika.

Berdasarkan penelitian yang dilakukan oleh Mosik dan Maulana. ${ }^{[3]}$ disimpulkan bahwa pendekatan konflik kognitif dalam pembelajaran fisika mempunyai pengaruh yang signifikan terhadap miskonsepsi fisika. Yang menyatakan rata-rata miskonsepsi kelas eksperimen lebih kecil dari rata-rata miskonsepsi kelas kontrol diterima. Selain itu pendekatan konflik kognitif dalam pembelajaran fisika mempunyai pengaruh yang signifikan terhadap hasil belajar fisika.

Hasil penelitian di atas yang dilakukan terpisah memberi gambaran bahwa problem solving laboratory dan pendekatan konflik kognitif mempunyai pengaruh terhadap miskonsepsi pada siswa. Namun sejauh ini belum ada penelitian yang menggabungkan antara problem solving laboratory dan pendekatan konflik kognitif terhadap perubahan konsep.

Salah satu kelebihan problem solving laboratory yaitu terintegrasi dengan pemberian materi pembelajaran, diterapkan melalui pendekatan konflik kognitif yang berpengaruh terhadap pemahaman konsep siswa. Dalam pemberian materi siswa dilibatkan secara aktif untuk mengkomunikasikan dua atau lebih rangsangan berupa sesuatu yang berlawanan atau berbeda kepada peserta didik, agar terjadi proses internal yang intensif dengan melakukan reorganisasi pengetahuan yang telah tersimpan dalam struktur kognitifnya. Berdasarkan penjelasan tersebut, dapat diduga bahwa problem solving laboratory yang menggunakan pendekatan konflik kognitif dapat menghasilkan perubahan konsep.

\section{METODE PENELITIAN}

Jenis penelitian yang digunakan adalah jenis penelitian dengan rancangan eksperimen kuasi. Untuk penelitian ini digunakan 1 kelas eksperimen dan 1 kelas kontrol. Adapun desain penelitian menggunakan RancPangan PratesPascates yang tidak ekuivalen (the non equivalen, pretest-postest design).

Tabel 1 Desain Penelitian

\begin{tabular}{|c|c|c|c|}
\hline Group & Pre-test & Treatment & Post-test \\
\hline A (KE) & O & X & O \\
B (KK) & O & - & 0 \\
\hline
\end{tabular}

Keterangan:

$X$ : Problem solving laboratory menggunakan pendekatan konflik kognitif

O : Tes yang diberikan (pretest dan posttest)

A : Kelompok eksperimen

B : Kelompok kontrol

: Pembelajaran konvensional

Penelitian bertempat di SMA Negeri 5 Palu. Penelitian ini dilaksanakan pada bulan Maret sampai April. Populasi dalam penelitian ini adalah seluruh siswa Kelas XI IPA SMA Negeri 5 Palu tahun pelajaran 2014/2015 yang terdiri dari 4 kelas. Pengambilan sampel dilakukan tanpa penugasan random dan menggunakan kelompok yang sudah ada (inact group). Sampel dalam penelitian ini adalah siswa siswa Kelas XI IPA 2 dan XI IPA 3 yang terbagi menjadi kelas eksperimen dan kelas kontrol, dimana Kelas XI IPA 3 sebagai kelompok kelas eksperimen dan Kelas XI IPA 2 sebagai kelompok kelas kontrol.

\section{Hasil Analisis Item}

Instrumen yang digunakan untuk mengumpulkan data dalam penelitian ini yaitu tes perubahan konsep dalam bentuk essay yang berjumlah 5 nomor dengan materi pelajaran Hukum Archimedes. Sebelum digunakan, instrumen terlebih dahulu divalidasi oleh validator ahli kemudian diuji cobakan pada kelompok yang bukan merupakan subjek penelitian yaitu siswa Kelas XII IPA 4 SMA Negeri 5 Palu yang berjumlah 28 siswa.

\section{HASIL PENELITIAN DAN PEMBAHASAN}

\section{Hasil Tes Perubahan Konsep Tentang Hukum Archimedes}

Setelah dilakukan perhitungan perubahan konsep tentang Hukum Archimedes diperoleh data hasil penelitian rerata nilai pretest-posttest kelas eksperimen dan kelas kontrol pada tabel berikut:

Tabel 2 Perbandingan rerata nilai pretest kelas eksperimen dan kelas kontrol

\begin{tabular}{|c|c|c|}
\hline Uraian & $\begin{array}{c}\text { Kelas } \\
\text { Eksperimen } \\
\mathbf{( \% )}\end{array}$ & $\begin{array}{c}\text { Kelas } \\
\text { Kontrol } \\
\mathbf{( \% )}\end{array}$ \\
\hline Nilai terendah & 20,0 & 14,0 \\
\hline Nilai tertinggi & 48,0 & 64,0 \\
\hline Nilai rata-rata & 33,9 & 33,7 \\
\hline
\end{tabular}


Tabel 3 Perbandingan rerata nilai pretest kelas eksperimen dan kelas kontrol

\begin{tabular}{|c|c|c|}
\hline Uraian & $\begin{array}{c}\text { Kelas } \\
\text { Eksperimen } \\
(\mathbf{\%})\end{array}$ & $\begin{array}{c}\text { Kelas } \\
\text { Kontrol } \\
\mathbf{( \% )}\end{array}$ \\
\hline Nilai terendah & 50,0 & 40,0 \\
\hline Nilai tertinggi & 80,0 & 66,0 \\
\hline Nilai rata-rata & 65,0 & 51,0 \\
\hline
\end{tabular}

Adapun perolehan nilai rata-rata tes awal dan tes akhir dari kelas ekperimen dan kelas kontrol dapat dilihat pada Gambar 1 dan Gambar 2 berikut:

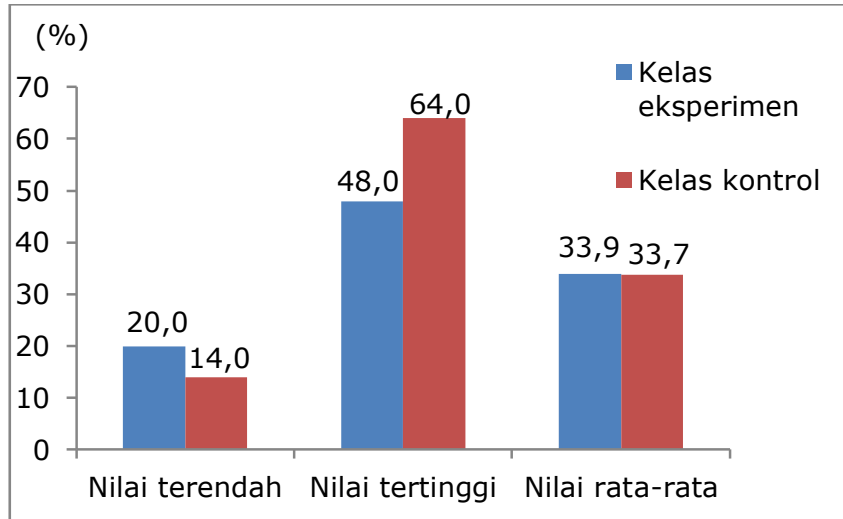

Gambar 1 Grafik perbandingan rerata nilai pretest pada kelas eksperimen dan kelas kontrol

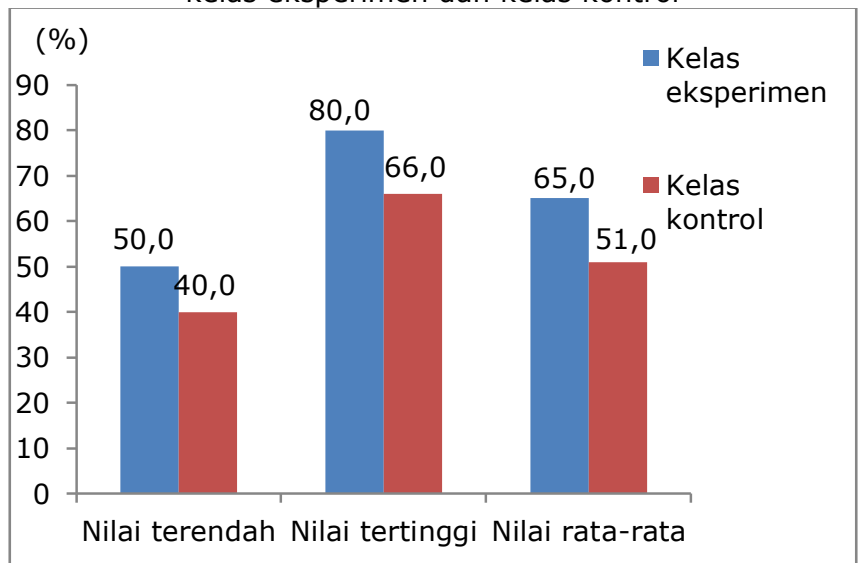

Gambar 2 Grafik perbandingan rerata nilai posttest pada kelas eksperimen dan kelas kontrol

Berdasarkan Gambar 1 dapat dilihat bahwa tidak terdapat perbedaan yang mencolok hasil tes awal fisika pada kelas eksperimen dan kelas kontrol tersebut. Pada Gambar 2 dapat dilihat bahwa terdapat perbedaan hasil tes akhir pada kelas eksperimen dan kelas kontrol, dimana hasil tes akhir pada kelas eksperimen lebih tinggi dari pada hasil tes akhir pada kelas kontrol.

\section{Uji Hipotesis (Uji-t)}

Uji ini dimaksud untuk melihat adanya pengaruh metode pembelajaran yang digunakan pada perubahan konsep siswa dan mengetahui kelas mana yang lebih baik, apakah kelas eksperimen atau kelas kontrol dan juga untuk memastikan apakah hipotesis yang diajukan dapat diterima atau ditolak.

Kriteria pengujian $\mathrm{H}_{0}$ diterima Jika $\mathrm{t}<t_{1-\alpha}$ dan tolak $\mathrm{H}_{0}$ jika $\mathrm{t}$ mempunyai harga-harga lain dimana $\propto=0,05$. Berdasarkan hasil perhitungan uji-t diperoleh taraf signifikan $\alpha=0,05$ dan $\mathrm{dk}=\left(\mathrm{n}_{1}+\mathrm{n}_{2}-2\right)=31+30-2=59$. Berdasarkan perhitungan, diperoleh data hasil analisis uji hipotesis pretest kelas eksperimen dan kelas kontrol yaitu $t_{\text {hitung }}=0,10<t_{\text {tabel }}=0,73$ yang berarti nilai $t_{\text {hitung berada pada daerah }}$ penerimaan $\mathrm{H}_{0}$. Dengan kata lain, bahwa tidak terdapat perbedaan pemahaman konsep antara kelas eksperimen dan kelas kontrol sebelum diberi perlakuan. Hasil uji hipotesis posttest kelas eksperimen dan kelas kontrol menunjukan $t_{\text {hitung }}=14,22>t_{\text {tabel }}=0,73$ yang berarti $\mathrm{H}_{0}$ ditolak dan $\mathrm{H}_{1}$ diterima. Dapat dilihat bahwa ada perbedaan secara signifikan perubahan konsep Hukum Archimedes pada tes akhir antara kelas eksperimen dan kelas kontrol.

\section{Pembahasan}

Penelitian ini menggunakan dua kelas yaitu kelas eksperimen dengan menerapkan metode problem solving laboratory menggunakan pendekatan konflik kognitif dan kelas kontrol dengan menerapkan pembelajaran konvensional.

Setelah melakukan tes awal dan tes akhir, presentase perubahan konsep fisika siswa untuk konteks soal gaya apung, persamaan Hukum Archimedes, dan massa jenis dapat dilihat pada Gambar 3 berikut:

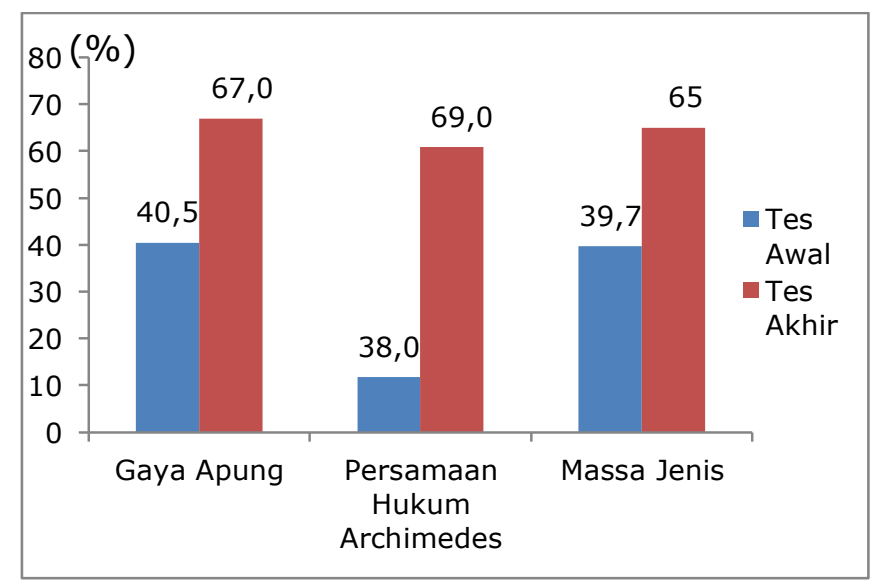


Gambar 3 Perbandingan nilai rata-rata tes awal dan tes akhir

Berdasarkan Gambar 3 tampak bahwa konteks soal persamaan Hukum Archimedes memiliki perbedaan dibandingkan dengan konteks soal lainnya, hal ini pada tes awal siswa belum memiliki gambaran mengenai persamaan Hukum Archimedes. Pada konteks soal gaya apung dan massa jenis siswa memiliki gambaran konsep-konsep tersebut pada kehidupan sehari, meskipun konsep yang dimiliki siswa masih keliru.

Secara deskriptif, hasil pengujian hipotesis yang telah dirumuskan sebelumnya menujukkan bahwa terdapat pengaruh perubahan konsep fisika yang belajar melalui metode problem solving laboratory menggunakan pendekatan konflik kognitif dengan pembelajaran konvensional model ceramah dan diskusi. Setelah melakukan uji hipotesis dengan menggunakan uji-t satu pihak diperoleh nilai $t_{\text {hitung }}$ sebesar 14,22 dan nilai $t_{\text {tabel }}$ $=t_{(1-a)}=0,73$ pada taraf signifikan $a=0,05$. Hasil tersebut menujukkan nilai $t_{\text {hitung }}$ memiliki harga lain yaitu 14,22 $\mathrm{H}_{1}$ diterima dan jika $t_{\text {hitung }}<t_{0,95}$ yang berarti hipotesis $\mathrm{H}_{0}$ diterima. Dengan kata lain, terdapat terdapat pengaruh perubahan konsep fisika siswa yang belajar melalui problem solving laboratory menggunakan pendekatan konflik kognitif (kelas eksperimen) dibandingkan dengan pembelajaran konvensional model ceramah dan diskusi (kelas kontrol).

Pembelajaran problem solving laboratory dapat membantu siswa menemukan masalah dan memecahkannya berdasarkan informasi yang diterima. Melalui problem solving laboratory siswa tidak merasa jenuh dan akan termotivasi untuk mencari jawaban dari setiap permasalahan yang ditemui dalam kehidupan sehari-hari. Dalam pembelajarannya, diadakan tahap pre-eksperimen yang berbentuk diskusi untuk mengetahui prediksi siswa terkait pertanyaan-pertanyaan yang ada pada LKS. Hal ini sesuai dengan teori yang dikemukakan oleh Feranie $d k k^{[4]}$, di mana salah satu tujuan problem solving laboratory adalah mengobservasi sebuah peristiwa yang memerlukan penjelasan yang tidak mudah sehingga mereka menyadari bahwa diperlukan ilmu untuk menjawabnya dan mendapatkan apresiasi kesulitan dan kegembiraan saat melakukan eksperimen.

Perubahan konsep terjadi ketika konsep yang dipahami siswa berbeda dari keadaan sebelumnya, konsep yang salah menjadi benar. Dalam hal ini, siswa menggunakan konsep- konsep yang ia miliki melalui pengalamannya dalam kehidupan sehari-hari untuk berhadapan dengan masalah konsep yang dikemukakan peneliti. Dan kemudian mengubah konsepnya yang tidak cocok lagi dengan konsep ilmiah yang telah mereka uji melalui praktikum model problem solving laboratory. Hal ini sesuai dengan teori konflik kognitif yang dikemukakan oleh Suparno ${ }^{[5]}$ bahwa ada dua tahap yang dilakukan dalam proses belajar untuk perubahan konsep yaitu tahap asimilasi dan akomodasi. Dengan asimilasi siswa menggunakan konsep-konsep yang telah mereka punyai untuk berhadapan dengan fenomena baru. Dengan akomodasi siswa mengubah konsepnya yang tidak cocok lagi dengan fenomena baru yang mereka hadapi.

Dalam pembelajarannya, problem solving laboratory menggunakan pendekatan konflik dapat menarik perhatian dan rasa ingin tahu siswa. Disamping itu siswa dapat membentuk ide baru berdasarkan pengalaman yang dimiliki melalui praktikum, memberi kesempatan kepada siswa untuk berfikir dan mengubah konsep-konsep fisika siswa yang tidak ilmiah, dan menuntut siswa untuk berfikir serta memiliki pengetahuan baru ketika hipotesis siswa tidak sesuai dan sesuai dengan pengamatan dan pada akhirnya dapat bermuara pada perubahan konsep siswa.

Perubahan konsep pada penelitian ini sesuai dengan penelitian Hariani $d k k^{[6]}$ yang menyimpulkan bahwa dengan menerapkan model problem solving laboratory dapat meningkat keterampilan proses sains dan hasil belajar fisika. Dari hasil penelitian tersebut memperlihatkan adanya pengaruh pembelajaran problem solving laboratory terhadap hasil belajar, dimana dengan meningkatnya hasil belajar siswa meningkat pula pemahaman konsepnya. Dalam penelitian Setyowati $d k k^{[7]}$ juga menyebutkan bahwa pendekatan konflik kognitif dalam pembelajaran fisika materi tekanan mampu menumbuhkan kamampuan berpikir kritis, pemahaman konsep dan hasil belajar kognitif siswa. Berdasarkan teori dan penelitian terdahulu serta penelitian yang dilakukan peneliti, jelas bahwa metode problem solving laboratory menggunakan pendekatan konflik kognitif dapat mempengaruhi perubahan konsep fisika siswa, tidak sekedar teoritik dan dapat dijadikan salah satu alternatif model pembelajaran dalam kegiatan belajar mengajar.

\section{KESIMPULAN}


Berdasarkan hasil penelitian dan analisis data maka dapat disimpulkan bahwa:

1. Terdapat pengaruh problem solving laboratory menggunakan pendekatan konflik kognitif terhadap perubahan konsep fisika siswa kelas XI SMA Negeri 5 Palu.

2. Perubahan konsep terjadi ketika konsep yang dipahami siswa berbeda dari keadaan sebelumnya. Dalam hal ini siswa menggunakan konsep-konsep yang ia miliki untuk berhadapan dengan masalah konsep yang dikemukakan peneliti sehingga siswa mengalami konflik kognitif, dan kemudian mengubah konsepnya sesuai dengan konsep ilmiah yang telah di uji melalui praktikum.
[8] Arikunto, Suharsimi. 2010. Dasar-Dasar Evaluasi pendidikan (edisi revisi). Jakarta: Bumi Aksara.

\section{DAFTAR PUSTAKA}

[1] Budiharti, Rini. 2009. Identifikasi Sains Asli (Indigenous Science) System Pranata Mangsa Melalui Kajian Etnosains. Laporan Penelitian. Universitas Sebelas Maret Surakarta.

[2] N. Mustafit, A. Andi, Sulhadi. 2009. Implementasi Problem Solving Laboratory Sebagai Model Kegiatan Laboratorium Berbasis Inquiry Untuk Meningkatkan Pemahaman Konsep Kesetimbangan Benda Pada Mahasiswa Pendidikan Fisika Semester II Tahun Ajaran 2007/2008. Skripsi. FMIPA UNNES. http://lib.unnes.ac.id/2138/

[3] Mosik, P. Maulana. 2010. Usaha Mengurangi Terjadinya Miskonsepsi Fisika Melalui Pembelajaran Dengan Pendekatan Konflik Kognitif. Jurnal Pendidikan Fisika Indonesia.98-103. http://journal.unnes.ac.id.

[4] Feranie, A. Setiawan, A. Suhandi. 2005. Problem Solving Laboratory: Suatu Model Alternatif Inovasi Pembelajaran Dalam Kegiatan Praktikum Fisika Dasar. Proceeding Seminar Nasional Pendidikan MIPA. 22-33. Universitas Pendidikan Indonesia.

[5] Suparno, Paul. 2007. Metodologi Pembelajaran Fisika Konstruktivistik \& Menyenangkan. Yogyakarta: Universitas Sanata Dharma.

[6] F. Hariani, Sudarti, S. Astutik. (2014). Pengaruh Model Problem Solving Laboratory terhadap Keterampilan Proses Sains dan Hasil Belajar Fisika Siswa Kelas XI di SMA Negeri 2 Tanggul. Jurnal Pembelajaran Fisika. Vol.3, No.1. Universitas Jember. http://library.unej.ac.id.

[7] Setyowati, B. Subali, Mosik. 2011. Implementasi Pendekatan Konflik Kognitif Dalam Pembelajaran Fisika Untuk Menumbuhkan Kemampuan Berpikir Kritis Siswa Smp Kelas VIII. Jurnal Pendidikan Fisika Indonesia. 89-96. http://journal.unnes.ac.id. 